\title{
Independence of the Judiciary and Judges in Japan
}

\section{Yuichiro Tsuji}

\author{
I. Judge as Public Servants \\ II . History of the Japanese Constitution \\ III. Independence of the Judiciary \\ 1. Articles in the Japanese Constitution \\ 2. Iken Kojima Case \\ 3. Naganuma Case \\ 4. Teranishi Case \\ 5 . Judges' Independence \\ 6 . Judges' Salaries \\ IV . Review by the People \\ 1. Interpretation of Article 79 \\ 2. Problems with Article 79 \\ $\mathrm{V}$. Impeachment \\ 1. Committee for Suing Judges. \\ VI. Conclusion
}

\section{I . Judges as Public Servants}

Under the Japanese constitution, judges are servants for the people, who reside under sovereignty. Article 15 of the Japanese constitution ${ }^{1}$ states, "the people have the inalienable right to choose their public officials and to dismiss them. All public officials are servants of the whole community and not of any group thereof. Universal adult suffrage is guaranteed with regard to the election of public officials. In all elections, secrecy of the ballot shall not be violated. A voter shall not be answerable, publicly or privately, for the choice he has made."

As this text indicates, judges are public officials therefore, judges are re-

1 NIHONKOKU KENPO [CONSTITUTION], art. 15. 
quired to work as servants for the whole community in the judiciary. These servants are regulated in each governmental branch. ${ }^{2}$ For example, the National Personnel Authority controls government servants in the executive branch. The Authority was given power by the legislation stated in the Diet. Its mission is to secure fairness, neutrality, and consistency for the control and promotion of public servants in administrative offices. The Agency punishes public officials who do not exhibit fairness and neutrality; however, it still secures their salaries. Government officials have no basic legal rights for their labor, which the private sector workers take for granted. The Authority substitutes for them.

If personnel changes are under the influence of political power, the neutrality of public servants comes into doubt. Therefore, the Agency is independent of the executive branch to some extent. It provides regulations that bind the public officials, including those related to ranking, admission, and training.

Information from the National Personnel Authority ${ }^{3}$ is popular among the general public because it publishes the average salaries for Japanese workers in the private and public sectors, and it affects salary levels of those who work in the private sectors. The Authority publishes this information based on an official survey that indexes public officials' salaries. This survey investigates the average income of the general public in the public sectors, and gives us a general understanding of the Japanese economy. ${ }^{4}$

For example, in Japan there are 6, 477,000 national governmental officials and approximately 3,000,000 local governmental officials. ${ }^{5}$ Recommendations given by the Authority control only clerical workers, of which there are approximately 300,000 in the national government. ${ }^{6}$ Clerical workers include general executive branch officials, diplomats, revenue officials, jail security

2 Koji Sato, Kenpo (Seirin Shoin 1995), 637.

3 〈http://www.jinji.go.jp/top.htm〉

4 JinjiinKankoku, 〈http://www.jinji.go.jp/kyuuyo/f_kyuuyo.htm〉

5 Id. See also, 〈http://www.gyoukaku.go.jp/siryou/koumuin/shurui.pdf $\rangle$ 
workers, doctors, etc. The average private sector salary is 390,907 yen, and the average public sector salary is 391,770 yen. The survey reflects a salary difference of 863 yen; therefore, the Authority reduced the housing allowance.

The salary of the prime minister, which is under legislation, is 51, 410, 000 yen. $^{7}$

The position of the public servants in the executive branch is guaranteed by the legislation passed in the Diet.

\section{II . History of the Japanese Constitution}

The Japanese Constitution was enacted on May 3, 1947 after being promulgated on November 3, 1946. The current constitution was revised from the old Meiji Constitution in the Imperial Diet after the nationwide election. ${ }^{8}$

Interpretation of the constitution can take two approaches: one is textualist, and the other is originalist. Textualists think that those living today interpret the text of the statutes. Originalists think that the interpretation of the text is bound by the drafter's intent. ${ }^{9}$

Although we may see variations on these approaches, it is impractical to adopt the extreme approach of either side. By looking at these approaches, we may find interpretations that apply to any concerns we are confronted with. $^{10}$

6 Id.

7 Tokubetsushokuno Shokuinno Kyuyonikannsuru Houritsu, Law No. 252 of 1949.

8 Makoto Ohishi, Nihonkoku Kenpo Si, (Yuhikaku 2005). Tatsuo Sato, Isao Sato, Nihonkoku Kenpo Seiritsusi No. 3 (Yuhikaku 1994).

9 For the interpretation of text and practical reasoning model of statutory interpretation, William Eskridge, Philip Frickey and Elizabeth Garrett, Legislation (West 2001), 804. Also, Stephen Breyer, Active Liberty (Random House, Inc. 2005), 1-34. Antonin Scalia \& Bryana, Garner, Making Your case (Thomson/ West 2008), 39-56. Scalia, A Matter of Interpretation, (Princeton University Press 1997). 
Charles Kades at General Headquarters (GHQ), the Supreme Commander for the Allied Powers (SCAP), and Japanese government officials Toshiro Irie and Tatsuo Sato discussed a draft of the new Constitution article by article. According to Tatsuo Sato, Article 83 in the MacArthur draft, which deals with judiciary independence, stated, "All judges shall be independent in the exercise of their conscience and shall be bound only by this Constitution and the laws enacted pursuant thereto." ${ }^{11}$

Article 84 in the MacArthur draft states, "The Supreme Court is vested with the rule-making power under which it determines the rules of practice and of procedure, the admission of attorneys, the internal discipline of the courts, the administration of judicial affairs, and such other matters as may properly affect the free exercise of the judicial power. Public procurators shall be officers of the court and subject to its rule-making power. The Supreme Court may delegate the power to make rules for inferior courts to such courts." ${ }^{12}$

Both Japanese and American officials discussed this information carefully. ${ }^{13}$ At the direction of the GHQ, Article 84 text "the admission of attorneys" was revised to read "matters pertaining to." The text "Public procurators shall be officers" was deleted. According to Sato, a prosecutor was able to work under the ministry of the executive branch.

In MacArthur's notes, the article regarding impeachment was, "The Diet shall constitute from among its members a court of impeachment to try members of the judiciary against whom removal proceedings have been instituted. ${ }^{\prime 14}$ For this article, Sato insisted that if a judge lost his mind or became insane, it was improper for us to enact only impeachment. Accepting

10 Id. Frickey.

11 MacArthur's draft [Constitution of Japan (English)] on 16 Feb. 1946 is available at 〈http://www.ndl.go.jp/constitution/shiryo/03/076a_e/076a_etx.html〉

12 Id.

13 Tatsuo Sato, Isao Sato, NihonkokuKenpoSeiritsusi No. 3, 110-111.

14 Supra, note 11. 
this opinion, the article was revised as follows: "Judges shall not be removed except by public impeachment unless judicially declared mentally or physically incompetent to perform official duties." ${ }^{15}$

In the article regarding discipline, Sato argued that the judges were appropriately disciplined in the special disciplinary court. However, his argument was rejected. According to the American side, it was a matter of impeachment. ${ }^{16}$

In MacArthur's notes, the article regarding the position of judges was, "The Supreme Court shall consist of a chief justice and such number of associate justices as may be determined by the Diet. All such justices as may be determined by the Diet. All such justices shall be appointed by the Cabinet and shall hold office during good behavior but not after the attainment of the age of 70 years, provided however that all such appointments shall be reviewed at the first general election held following the appointment and thereafter at every general election held immediately following the expiration of ten calendar years from the next prior confirmation." The Japanese government argued that the text "good behavior" meant that it might be easy to remove a judge in the case of bad behavior, and thus weakened protection of the judges' positions. The American side accepted this.

The article regarding salary compensation in MacArthur's notes was, "All such justices shall receive, at regular, stated intervals, adequate compensation which shall not be decreased during their terms of office." The Japanese government argued that this text did not need to be included in the constitution. They said that if this text was included, it was also necessary to include the special proceedings for disciplinary actions resulting in salary reductions. The American side considered this, but said that it related to the particular judge's position. One member on the Japanese side said that it might be sufficient to state that judges were not allowed salary raises. After this discus-

15 Id. At 138, 140.

16 Id. 
sion, the text remained untouched. ${ }^{17}$

The article regarding inferior court judges was, "The judges of the inferior courts shall be appointed by the Cabinet from a list which for each vacancy shall contain the names of at least two persons nominated by the Supreme Court. All such justices shall hold office for a term of ten years with privilege of reappointment and shall receive, at regular, stated intervals, adequate compensation which shall not be decreased during their terms of office. No judge shall hold office after attaining the age of 70 years." Although there was no opinion given from both sides, the final version omitted "at least two persons." ${ }^{18}$

\section{Independence of the Judiciary}

\section{Articles in the Japanese Constitution}

Along with the guarantee of public officials' positions in the executive branch, those in the judiciary are considered from another perspective, called judiciary independence. The judiciary is independent of political, executive, and legislative power, and its members form legal intuition in their minds regarding the cases in front of them.

The following articles of the Japanese Constitution relate to this issue:

Article 77. The Supreme Court is vested with the rule-making power under which it determines the rules of procedure and of practice, and of matters relating to attorneys, the internal discipline of the courts and the administration of judicial affairs. Public procurators shall be subject to the rulemaking power of the Supreme Court. The Supreme Court may delegate the power to make rules for inferior courts to such courts.

Article 78. Judges shall not be removed except by public impeachment unless judicially declared mentally or physically incompetent to perform official

17 Id. At 141.

18 Id. 
duties. No disciplinary action against judges shall be administered by any executive organ or agency.

Article 79. The Supreme Court shall consist of a Chief Judge and such number of judges as may be determined by law; all such judges excepting the Chief Judge shall be appointed by the Cabinet. The appointment of the judges of the Supreme Court shall be reviewed by the people at the first general election of members of the House of Representatives following their appointment, and shall be reviewed again at the first general election of members of the House of Representatives after a lapse of ten (10) years, and in the same manner thereafter. In cases mentioned in the foregoing paragraph, when the majority of the voters favor the dismissal of a judge, he shall be dismissed. Matters pertaining to review shall be prescribed by law. The judges of the Supreme Court shall be retired upon the attainment of the age as fixed by law. All such judges shall receive, at regular stated intervals, adequate compensation which shall not be decreased during their terms of office.

In the Meiji era, the judiciary belonged to the Emperor. Judges exercised their duties under the name of the Emperor. In this era, the Meiji Constitution followed the Prussian Constitution, which maintained a strong Emperor and special tribunals for royal and military courts. Since World War II, the current Japanese Constitution has followed the United States' Constitution. Under this, there is no special tribunal independent of the general court hierarchy.

In the hierarchy, the sole Supreme Court has 15 judges. One is the President, and the others are judges. The President of the Supreme Court is designated by the Cabinet and is appointed by the Emperor. Generally, the designated judges in the Supreme Court are over 40 years old. At least 10 judges must have more than 10 years' experience in the legal profession. These candidates include the Chief judge in the high court, judges (Hanji), judges in the summary court, prosecutors, lawyers, or professors.

All courts other than the Supreme Court are called inferior courts. Judges 
in the inferior courts are appointed by the Cabinet. The list of nominees is prepared by the Supreme Court. Today, this list is drafted by the inferior designating advisory committee, and the Supreme Court submits the number to be designated, plus nominates one of the candidates. ${ }^{19}$

According to these articles, judges come under the regulations of the judiciary. The rules are promulgated by the Supreme Court according to Article 77. The Diet can pass legislation regarding Article 77, such as rules of procedure and practice, and matters relating to attorneys. The internal discipline of the courts and the administration of judicial affairs are understood to fall exclusively under the arm of the judiciary. If the law conflicts with judiciary rules regarding internal matters, the rule is superior to the statutes. In other areas, the statutes are superior.

The judges shall be independent in the exercise of their conscience and shall be bound only by this Constitution and the laws. The conscience means the professional legal mind of a professional judge, and excludes subjective emotions.

Although not clearly stipulated by the text of Article 79, judiciary independence holds two meanings: one is independence of the judiciary, and the other is that of the judges themselves.

\section{Iken Kojima Case}

Before examining cases that fall under the current Japanese Constitution, it is important to examine one famous case from the Meiji era. It is known as the Iken (Korekata) Kojima case. ${ }^{20}$ In 1891, just after the Meiji Restoration period, the prince of the Russian empire, Nicholai Aleksandrovich Romanov, was attacked by a police officer. This became known as the "Ohtsu case," stemming from the name of the place of attack. In 1867, Shogun Yoshinobu Tokugawa, the head Samurai in the Edo government, restored sovereign

19 Sato, Kenpo, 310. SaibanshoHo, art. 39, 40.

20 Seiichiro Kusunoki, Kojima Iken (Chuko Shinsho 1997). Ohishi, Nihonkoku KenpoSi, 250. 
power to the Emperor.

Just after this restoration, civil war took place between the Edo government and the new Meiji government. Although the Meiji government stimulated the Great Imperial Constitution (the Meiji Constitution) in 1889, in 1887, Takamori Saigo, a hero of the Restoration, fought in the Kyushu area against the Meiji government to defend the old fighters who lost their jobs due to the restoration. Many old samurais lost their sword-carrying privileges. Ten thousand people died in this civil war. Takamori Saigo fought for them, but lost.

When the Ohtsu case occurred, the Meiji government was still struggling to maintain domestic safety and also to maintain equal diplomatic relationships with European countries. At that time, people were surprised by this case because the attacking police officer, Sanzo Tsuda, was employed by Prince Nicholai himself. Sanzo Tsuda tried to assassinate the Prince, but missed. According to Tsuda's statement, he did not like the Russian attitude regarding Japan's northern territories.

It was clear that the executive power in the Meiji government held no power over Russia. The government insisted that the defendant be subject to capital punishment under Article 166 of the old criminal code, which decreed that capital punishment take place if a person conducted an attack on a Japanese emperor or his family. At that time, there was no article relating to the attack of a foreign prince.

Under pressure from the executive branch, Iken Kojima, the chief justice of the old Japanese Supreme Court, persisted. Iken Kojima insisted that if there was no article related to an attack against the royal family of a foreign government, the court could not render capital punishment. His opposition was accepted, and the defendant was sentenced to life imprisonment. The Minister of Justice, Yamada, resigned.

Some say that this case was famous for demonstrating judiciary independence and the separation of power. However, criticism remains. Under formal proceedings of the criminal procedure, the defendant should have been tried 
in the district court of Ohtsu where the assassination attempt occurred; however, the case was moved to the Supreme Court. Additionally, the judge who heard the case was not Chief Justice Kojima. As the Chief Justice, Kojima intervened with the judge hearing this case. Therefore, while judiciary independence was protected, that of the judges was in doubt. ${ }^{21}$

\section{Naganuma Case}

Even under the current Japanese Constitution, independence of judges comes into doubt when reviewing the Naganuma case ${ }^{22}$. All Japanese law students must study the Naganuma case their first year of law school.

Construction of the Japanese self defense force airbase was planned in Naganuma City, Yubari, Hokkaido. This project was designed for the disposal of antiaircraft missiles. As construction in the region was originally prohibited due to existing forest protection laws ${ }^{23}$, the Ministry of Agriculture removed the ban. The inhabitants of the region argued that removal of the ban did not hold the public at interest, and that therefore the removal was illegal. They insisted that the Japanese self defense force was acting unconstitutionally.

At the trial, Judge Shigeo Fukushima decided that the self defense force had acted unconstitutionally. ${ }^{24}$ He indicated a violation of Article 9 of the Japanese Constitution. Removal of the construction ban was unconstitutional because no public interest was recognized. This infringed on the citizens' right to live in peace, as stipulated in the preamble of the Japanese Constitution.

21 Nobuyoshi Ashibe, Kenpo (4 ${ }^{\text {th }}$ edition) (Iwanami Shoten 2007), at 341.

22 SAIKO SAIBANSHO [Sup. Ct.] Sep. 9, 1982, Showa 52 (gyou tsu) no. 56, 36 SAIKO SAIBANSHO MINJI HANREISHU [MINSHU] 1679. This case is called Naganuma case in Japan. Shigeo Fukushima, Yosikazu Ohide, Asaho Mizushima, Naganuma Jiken Hiraga Shokan (Nihon Hyoronsha 2009).

23 Sin Rin Ho (Law of Woods), Law of No. 249 of 1951.

24 Sapporo Chiho Saibansho [Sappoto dist. ct.] Sep. 7, 1973, Showa 44 (gyou u) no. 23, 140 HANREI TAIMUZU [HANTA] 298 (Japan). 
In this trial, the president of the district court of Hokkaido, Kenta Hiraga, sent one letter to the Shigeo Fukushima. Judge Kenta said that this letter was simply advice from one senior person. This letter included advice pertaining to the case Fukushima was hearing.

The high court determined that construction of a dam would remove the danger caused by construction of the base. ${ }^{25}$ The inhabitants lost interest in the case once the dam construction was announced, and the high court avoided the issue of whether the self defense force went against Article 9. The Supreme Court dismissed the case due to lack of standing of the inhabitants, and the Supreme Court concluded that the letter sent by the Kenta was not appropriate, and issued him a warning. ${ }^{26}$

\section{Teranishi Case}

When law students pass the bar examination, they enter the Japanese Legal Training Institute (JLTI) for one to two years. ${ }^{27}$ During this training, people are assigned to and recruited by senior judges, prosecutors, and lawyers. Most of them choose to be lawyers.

In the first five years working as a Hanji-ho with other two judges, and until their re-appointment, young judges cannot render any decisions by themselves. Judges usually work for ten years after their first appointment by the cabinet, at which point they are re-appointed. There are around 1, 000 Hanji-ho in Japan. After re-appointment, Hanji-ho judges can become Hanji judges, and can then render decisions by themselves. ${ }^{28}$

In this case, Judge Kazushi Teranishi held the position of "Hanji-ho" after training in the JLTI. Judge Kazushi Teranishi was attending a symposium

25 Sapporo Koto Saibansho [Sapporo high court] Aug. 5, 1976, Showa 48 (gyou ko), no. 2, 135 HANREI TAIMUZU [HANTA] 338 (Japan).

26 Sato, Kenpo, 328. Ashibe, Kenpo, 342.

27 This institute was established in 1947, according to SaibanshoHo [Law of the court], Law No. 59 of 1947. 〈http://www.courts.go.jp/saikosai/sihokensyujo/ sihokensyujo.html $>$

28 SaibanshoHo, art. 5, 23, 27, 31-2, 40, 41, 42 etc. 
regarding legislation of wiretapping by the government. Kazushi was invited to this symposium as a panelist; however, when the President of the district court objected to his attendance, he attended only as an observer. During the symposium, he stated to the audience that he was prevented from attending as a panelist, but was not prohibited from attending as a citizen.

He was tried under Bungen shobun in the judiciary. ${ }^{29}$ Bungen does not take the form of disciplinary action or dismissal by the executive or legislative branches because the judges' positions are protected by the Constitution. Bungen falls under the jurisdiction of the high or Supreme Court, and their sanctions serve only as warnings and fines, not removal. Even if this disciplinary action is taken against judges in the judiciary, their retirement money is paid. According to Article 78, mental or physical incompetence are usually the reasons for removing judges. In this case, Kazshi had no mental or physical issues. He appealed the decision.

The Supreme Court did not accept his appeal. According to the Supreme Court, a judge needs to work neutrally and fairly. Since the Supreme Court has judicial review, Kazshi's political actions were strictly prohibited. If political expression by the judge was prohibited, his freedom to speak might have been restricted. If the purpose was legitimate, however, the measure and the purpose were rationally related and the lost and acquired interests would be balanced; therefore, Bungen shobun was sustained. This action was taken to prevent the corruption. The judge's burden was indirect and incidental. ${ }^{30}$

There is some criticism of this case. The Supreme Court itself decreed that whether a re-appointment takes place is up to the free discretion of the Supreme Court. One possible interpretation of the text is that the judge

29 SaibanKanBungenho, Law No. 127 of 1947.

Saiko Saibansho [Sup. Ct.] Dec. 1, 1998, Heisei 10 (Bun ku) no. 1, 52 SAIKO SAIBANSHO MINJI HANREISHU 1761. This case is called Teranishi case in Japan.

30 Saiko Saibansho [Sup. Ct.] Nov. 6, 1974, Showa 44 (a) no. 1501, 28 SAIKO SAIBANSHO KEIJI HANREISHU 393. This case is called Sarufutsu case in Japan. This reasoning was applied in Teranishi case. 
loses his positions after ten years. It means that the purpose of Article 80 is to exclude the inappropriate, and judges should be reappointed except under special, extreme circumstances. ${ }^{31}$

\section{Judges' Independence}

In the Japanese constitution, the independence of judges was stipulated in Article 76, Section 3. The independence of the judiciary means independence of both the judiciary and the judges. The purpose of this article is that a judge must exercise his authority independently of political power or of executive and legislative power. Judiciary authority is fragile, and the Japanese constitution protects the position of judges in Article 78; therefore, judges can freely exercise their power to shape their legal mind when hearing cases. Judges work in the general courts until retirement at age 65 and in the Supreme Court until age 70. Measures for removal of judges include: impeachment; review by the people (Article 79); and Bungen-saiban, which is disciplinary action taken against judges (Article 78)..$^{2}$

\section{Judges' Salaries}

Protection of judges guarantees that a judge can work fairly and not be subjected to pressure or economical conditions. This is part of the independence of judges. Therefore, a reduction in the number of judges goes against Article 79. In 2002, however, the National Personnel Authority declared a two percent reduction of public officials for the first time since 1948. In 2002 , public sector payment was higher than that of private officials. This reduction was declared to close that gap. Following this reduction, judges' salaries were reduced.

As stated in Article 80, "the judges of the inferior courts shall receive, at regular stated intervals, adequate compensation which shall not be de-

31 Sato, Kenpo 314. Ashibe, Kenpo, 334-5.

32 Id. Ashibe, Kenpo, 339-. 
creased during their terms of office." Therefore, the salary of certain judges in the judiciary should not be reduced. However, reduction of all public officials' salaries, including judges', may not go against Article 80.

Judges' salaries are classified into rankings from 12 to $17^{33}$ Their salaries follow those of prosecutors. The President of the Supreme Court earns 39, 674, 880 yen per year, or 2, 065, 000 per month. The first judges (Hanji) earn 10,211, 459 yen after working for eleven years. The lowest ranking is 17 (summary court judges), and Hanji-ho judges rank twelfth, earning 227,000 yen. $^{34}$

IV . Review by the People

\section{Interpretation of Article 79}

Article 79 provides, "the appointment of the judges of the Supreme Court shall be reviewed by the people at the first general election of members of the House of Representatives following their appointment, and shall be reviewed again at the first general election of members of the House of Representatives after a lapse of ten (10) years, and in the same manner thereafter."

This offers another method of removing judges..$^{35}$ This system follows that of Missouri State in the United States. The purpose is to respect the rule of the law, and ensure the Supreme Court is controlled democratically.

Although there are several interpretations of Article 79 , it is generally viewed as a recall system. Another interpretation considers Article 79 to indicate a confirmation system. After designation by the Cabinet as outlined in

33 SaibankannoHoshunikansuruHouritsu, Law No. 75 of 1948. Sato, Kenpo, 329.

34 Id.

35 Saiko Saibankan Kokumin Sinsaho, Law No. 136 of 1947. For the United States system, William A. Fletcher (translated by Yuichiro Tsuji), The Structure of the American Judiciary and the Appointment of Judges, 24(1-2) Surugadai Journal of Law and Politics 265-280 (2009-2010). 
Article 6, a review by the people (Article 79) completes his confirmation. Only after the review by the people takes place are the citizens to review whether or not Supreme Court judges are eligible. However, this interpretation does not explain the problem of the time lag between the designation and review by the people.

Although the details of this system were provided by the law and these interpretations, this proceeding is not very popular among the people.

\section{Problems with Article 79}

The review by the people has been criticized. ${ }^{36}$ The review form is handed to voters at the first general election of members of the House of Representatives, following the members' appointments. This paper indicates one warning: "First, you put an $\mathrm{X}$ in the box of the judge if you think he should resign. Second, you leave it blank if you think he should not resign.” The name and the blank boxes are indicated in the papers. If voters think one of the Supreme Court judges is not eligible, an $\mathrm{X}$ is to be put in the box. If they put another sign, such as an $\mathrm{O}$, it is deemed void. If it is left blank, it means the voters approve of the judges. The order of judges on the list is decided by drawing lots. Statistics says that if a judge is placed on the right side of the list, his non-confidence is apt to be more supported. This is probably because the voters review the list from the right to the left. In theory, the voters could select not to receive this paper at voting time, because you cannot see other marks but $\mathrm{X}$, it is substantially impossible to abstain from expressing to one judge.

The problem with this system is that the Japanese people do not know the names of the Supreme Court judges. Some have criticized this system because it is ineffective. Although some say that this system should be abolished, if the purpose of this system is to put the judiciary under the democratic control, we should make improvements upon the system, not abolish it.

36 See also, Ashibe, Kenpo, at 334. Sato, Kenpo, 103. 


\section{Impeachment}

\section{Committee for Suing Judges.}

The final way to remove a judge is by impeachment. ${ }^{37}$ Before presenting to the impeachment court in the Diet, a committee is consulted. Anyone can bring a complaint to the committee. This committee has 20 members: 10 from the House of the Representatives, and 10 from the House of Councilors. ${ }^{38}$ Although the impeachment court is opened to the public, the arguments presented at the committee proceedings are not open to the public. This committee decides if the judge should be brought to the impeachment court, or to dismiss or postpone the prosecution.

The impeachment court needs two-thirds of the members of the impeachment court. Impeachment proceedings commence for two reasons. One is clear infringement of professional duties, or extreme neglect of the duties. ${ }^{39}$ The other is delinquency which results in loss of honor and authority as a judge, regardless of where the delinquency took place. This court has the final word, and no appeal process is provided. After the decision is made, however, the impeached judge can make a complaint and recover his position thereafter.

There are several cases examples regarding impeachment: ${ }^{40}$

1) A judge allegedly traveled with one of his attorney friends to the judge's former place of employment. The travel was suggested by the attorney, and while they traveled for one week, the judge was absent without receiving any permission to travel from the court. In addition, this judge was communicating on behalf of the attorney to attain business contracts. Once the business transaction was vacated, the judge negotiated with the people

\footnotetext{
37 Saibankan Dangaiho, Law No. 137 of 1947.

$38\langle\mathrm{http}: / /$ www.dangai.go.jp/>

39 Saibankan Dangaiho, art. 2.

40 Supra, note 30. See also, 〈http://www.sotsui.go.jp/index.html〉, 〈http://www. dangai.go.jp/index.html〉.
} 
involved. When the police investigated, the judge persuaded the chief of police that this was not the case. ${ }^{41}$

The judge was prosecuted, but not impeached.

2 ) A judge learned that his acquaintance was soon to be investigated under the allegation that he acquired a substantial amount of textile goods to sell on the black market. The judge told his acquaintance to dispose of the goods. The acquaintance informed the judge that he would be tried by the court on the summary order, and asked for advice about what he should do. The judge told him to bring the case under official proceedings. This case was not assigned to the judge, but he asked for the case to be moved to his own court, without formal proceedings. At the trial, and under his authority, the judge allegedly told the witness to give false evidence.

The judge was prosecuted, but not impeached.

3 ) A judge left many cases carelessly untouched. In 395 cases with summary orders, the judge did not send due notices to the defendants in time. The notices became void, and in two-thirds of the cases the prosecutors gave up. The judge also signed blank warrant papers, and told his official to keep them. Without notice given to the defendant and the judge himself, the warrant was issued.

In addition, when told by one of his friends that his money was embezzled by a mediator, the judge ordered the mediator to attend court, and asked him to pay back the money.

Moreover, the judge summoned defendants to attend court without using a postal service to send the summary orders. When some defendants did not attend, the judge arrested them. Since this judge did not tell officials to compile these cases in the record, the documents were discarded. The judge told the court police to deal with the cases properly. The judge did not sign the roll book for a long time, and also did not warn officials about not signing the roll book.

41 These cases are in http://www.dangai.go.jp/. 
This judge was prosecuted and impeached.

4 ) After work one day, a judge and plaintiff went to the plaintiff's hotel using the plaintiff's motorcycle. At the hotel, the plaintiff treated the judge to dinner. After this incident became known to the president of the court the judge served in, the judge brought a bottle of sake to a mediator for the case, and asked for good treatment. After two years of investigation, the judge paid back all the people involved.

The judge was prosecuted and impeached. His position was later recovered.

5 ) A judge telephoned the Prime Minister, who was the Attorney General (the Public Prosecutor General). He informed the Prime Minister of a false investigation, and asked for advice about how to deal with the ex-Prime Minister and the president of the Liberal Democratic Party. This conversation between the Prime Minister and the judge was recorded on tape. Knowing the tape contained a politically critical issue, the judge replayed it in front of two reporters in a Tokyo hotel.

The judge was prosecuted and impeached. His position was recovered later.

6 ) A judge received one set of foreign-made golf clubs, one caddie bag, two golf clubs, one set of golf tools, and two suits.

The judge was prosecuted and impeached. His position was later recovered.

7 ) A judge solicited three prostitutes, knowing that they were under the age of 18 . The judge was prosecuted and impeached.

\section{Conclusion}

As officials working in the executive branch and as stated under Article 15 of the Japanese Constitution, judges in the judiciary are public servants for the people. Their mission is to interpret the text of the Constitution and statutes when hearing court cases. 
Sixty years ago, the Japanese Constitution was drafted by both the American and Japanese people. It is important, though not critical, to interpret the records and intent of the drafters. We are not bound to the hand of the dead. Extreme textualist and originalist approaches are not adopted. By examining these arguments, however, we gain insight that can be used when reviewing the system and text carefully, and thus come to a more thorough understanding of the purpose.

The Kojima, Naganuma, and Teranishi cases suggest that both the judiciary and judges should be independent. Under the current Constitution, we examined one questionable case of Judge Teranishi. Although we understand the mission of the judges is to work neutrally and fairly, as written by the Supreme Court, it is still questionable as to independence of judge.

The judges' salaries are guaranteed by the Constitution and regulated by the law. The salary is based on those of private sector workers. It is against the Constitution to reduce only the salaries of certain classes of judges, but it is not against the Constitution to reduce all of the salaries in the judiciary.

The review of Supreme Court judges by the people was conducted at the first general election of members of the House of Representatives following their appointment, and shall be reviewed again at the first general election of members of the House of Representatives after a lapse of ten years, and in the same manner thereafter. This system is questionable because many Japanese people are unaware of the judges' names and of the Supreme Court cases.

The only way to remove a judge is through impeachment. The Japanese Constitution stipulates impeachment in the parliament; therefore, the Diet organizes impeachment committees in cases where judges are being sued. The politicians decide if the judge should be impeached. To date, several judges have been sued and impeached. Some reasons for this were political, and others were not.

In Japan, we need to be vigilant against measurements that infringe on the independence of judges. The independence of the judiciary and judges is 
required for the formation of the legal mind to occur. Their duties can be fully exercised only after their positions become independent of the political powers of the executive and legislative powers.

\section{KEYWORDS}

Japan, Constitution, independence of judge, Ohtsu case Korekata Kojima, Naganuma case, Teranishi case.

(本研究は平成 22 年度駿河台大学特別研究助成費の採択を受けたプログラムの 一部である) 